\title{
In vitro antiviral efficacy of moroxydine hydrochloride and ribavirin against grass carp reovirus and giant salamander iridovirus
}

\author{
Xiao-Bo Yu, Xiao-Hui Chen, Li-Peng Shan, Kai Hao, Gao-Xue Wang* \\ College of Animal Science and Technology, Northwest A\&F University, Yangling, Shaanxi 712100, PR China
}

\begin{abstract}
Moroxydine hydrochloride (Mor) and ribavirin (Rib) have been reported to exhibit multi-antiviral activities against DNA and RNA viruses, but their antiviral activities and pharmacologies have seldom been studied in aquaculture. This paper has selected 3 aquatic viruses including a double-stranded RNA virus (grass carp reovirus, GCRV), a single-stranded RNA virus (spring viraemia of carp virus, SVCV) and a DNA virus (giant salamander iridovirus, GSIV) for antiviral testing. The results showed that Mor and Rib can effectively control the infection of GCRV and GSIV in respective host cells. Further study was undertaken to explore the antivirus efficiencies and pharmacological mechanisms of Mor and Rib on GCRV and GSIV in vitro. Briefly, compounds showed over $50 \%$ protective effects at $15.9 \mathrm{\mu g} \mathrm{ml}^{-1}$ except for the group of GSIV-infected epithelioma papulosum cyprinid (EPC) cells treated with Mor. Moreover, Mor and Rib blocked the virus-induced cytopathic effects and apoptosis in host cells to keep the normal cellular structure. The expression of VP1 (GCRV) and major capsid protein (MCP; GSIV) gene was also significantly inhibited in the virus-infected cells when treated with Mor and Rib. Cytotoxicity assay verified the 2 compounds had no toxic effects on grass carp ovary (GCO) cells and EPC cells at $\leq 96 \mu \mathrm{g} \mathrm{ml}^{-1}$. In conclusion, these results indicated that exposing GCRV-infected GCO cells and GSIV-infected EPC cells to Mor and Rib could elicit significant antiviral responses, and the 2 compounds have been shown to be promising agents for viral control in the aquaculture industry.
\end{abstract}

KEY WORDS: Moroxydine hydrochloride · Ribavirin · GCO cell · EPC cell · GCRV · GSIV • Apoptotic response

Resale or republication not permitted without written consent of the publisher

\section{INTRODUCTION}

Three different types of aquatic viruses - grass carp reovirus (GCRV), spring viremia of carp virus (SVCV) and giant salamander iridovirus (GSIV) have been identified as important pathogens that cause severe hemorrhagic symptom and almost $85 \%$ mortality in a wide range of naturally infected aquatic animal and amphibians (Björklund et al. 1995, Daszak et al. 1999, Attoui et al. 2002, Dong et al. 2011, Padhi \& Verghese 2012, Q. Wang et al. 2012).
The family Iridoviridae currently comprises 5 genera: Ranavirus, Lymphocystivirus, Megalocytivirus, Iridovirus and Chloriridovirus (Chinchar et al. 2005). GSIV is a large DNA virus belonging to the genus Ranavirus in the family Iridoviridae and has been reported in farmed Chinese giant salamanders in recent years (Dong et al. 2011, Geng et al. 2011). The clinical signs of giant salamanders infected with GSIV include skin and internal organ hemorrhage, limb swelling, and ulceration (Geng et al. 2011). SVCV is a single-stranded RNA virus belonging to 
the genus Vesiculovirus, and it can cause an acute hemorrhagic and highly contagious disease in cyprinids (Padhi \& Verghese 2012). GCRV, a doublestranded RNA virus belonging to the species Aquareovirus $\mathrm{C}$ in the family Reoviridae, is the most pathogenic aquareovirus that causes hemorrhagic disease with severe mortality in grass carp, and it has been known in China since 1983 (Attoui et al. 2002, Q. Wang et al. 2012). The biological characteristics and pathogenesis of GCRV, SVCV and GSIV have therefore been studied because all of these viruses cause severe economic losses in the aquaculture industry (Tidona et al. 1998, Koutná et al. 2003, Holopainen et al. 2009, Fan et al. 2013, Ma et al. 2014).

Moroxydine hydrochloride (Mor) is known to possess multi-antiviral efficacy against RNA and DNA viruses, but its antiviral activity and pharmacology has rarely been reported in aquaculture. Mor has been shown to be effective in the treatment of hepatitis $\mathrm{C}$, influenza symptoms, varicella-zoster, measles, mumps disease, tobacco mosaic virus, etc. (Sheppard 1994, Z. Wang et al. 2012, Gasparini et al. 2014, Magri et al. 2015). Ribavirin (Rib) was selected as a positive control in this study because this compound has several activities against aquatic viruses, such as rainbow trout rhabdovirus (Marroquí et al. 2007), GCRV (Zhu et al. 2015), chum salmon reovirus (DeWitte-Orr \& Bols 2007), infectious pancreatic necrosis virus and infectious hematopoietic necrosis virus (Hudson et al. 1988). In addition, Rib as an antiviral agent has many antiviral activities in the treatment of flaviviruses, paramyxoviruses, hepatitis virus, influenza-A virus, respiratory syndrome coronavirus, etc. (Leyssen et al. 2005, Kamar et al. 2010, Rowe et al. 2010, Chan et al. 2013). Although Mor and Rib exhibit excellent disease-resistant potency for targeting RNA and DNA viruses, little information exists on their efficacy and the mechanisms used by the 2 compounds on aquatic viruses. Therefore, further studies will be needed to close these knowledge gaps.

Immune regulation (Chen et al. 2013, Liu et al. 2014), vaccine development (He et al. 2011, Xue et al. 2013, Zhou et al. 2015) and antiviral agents (Yu et al. 2014) have been introduced to help control GCRV and GSIV in recent years. However, aquatic virus diseases are still difficult to efficiently control with vaccine in the aquaculture industry because the subtype specificity of vaccines has a relatively narrow antiviral spectrum (Hammond et al. 1999). Immune regulation has been widely accepted as a good method to improve the health of cultured aquatic animals and help them resist disease (Chen et al. 2013, Samanta et al. 2013), but it is not enough to effectively decrease mortality in severe outbreaks of virus disease. Furthermore, some antiviral agents directly inhibit transcription of the virus to reduce the replication in host cells and may regulate the immune system (Citarasu, 2010, Yu et al. 2014). However, there is a shortage of effective antiviral agents and lack of relevant research on the mechanisms that control GCRV and GSIV.

The present study was undertaken to determine the antiviral activity and potential mechanisms of 2 compounds on GCRV and GSIV in vitro by detecting the morphology, cell viability, virus titer, and viral gene expressions. The epithelioma papulosum cyprinid (EPC) cell line is known to be susceptible to infection with GSIV and SVCV (Koutná et al. 2003, Ma et al. 2014), and the findings in our study indicated that the grass carp ovary (GCO) cell line is susceptible to infection with GCRV, which is consistent with the findings of a previous study (Ke et al. 2013). The GCO cell line is known to be susceptible to viruses such as Cyprinus carpio spring viremia virus, Rana grylio virus, Paralichthys olivaceus lymphocystis virus (Zhang et al. 2003, Ou et al. 2014) and was used to replicate and propagate part of the virus. The EPC cell line represents a suitable in vitro model to study GSIV morphogenesis and characterize the GSIV replication cycle (Gao et al. 2012, Ma et al. 2014). Therefore, GCO and EPC cell lines can be used as stable in vitro models to perform some specific studies involving virus-host interactions and pharmacologic activity.

\section{MATERIALS AND METHODS}

\section{Cells, virus, antiviral compounds}

The GCO cell line, EPC cell line, GCRV and GSIV, were kindly provided by Prof. Ling-Bing Zeng of the Yangtze River Fisheries Research Institute, Wuhan, Hubei, China. SVCV was maintained in our laboratory. The EPC cells were cultured in MEM medium supplemented with $10 \%$ inactivated foetal bovine serum (FBS) (GIBCO BRL) and maintained in an incubator at $26^{\circ} \mathrm{C}$. GCO cells were cultured in M199 medium supplemented with $10 \%$ inactivated FBS and maintained in an incubator at $28^{\circ} \mathrm{C}$. The antiviral compounds, Mor (CAS No. 3160-91-6) and Rib (CAS No. 36791-04-5), were purchased from Aladdin Chemistry Co. 


\section{Virus infection and cell viability assays}

The virus infection and viral titres of GCRV and GSIV were determined by the standard $50 \%$ tissue culture infective dose $\left(\mathrm{TCID}_{50}\right)$ method, as described previously (Yu et al. 2014). GCO cells were susceptible to GCRV with titers approaching $2.24 \times$ $10^{7} \mathrm{TCID}_{50} \mathrm{ml}^{-1}$, and EPC cells were susceptible to GSIV and SVCV infection with virus titers approaching $1.58 \times 10^{5}$ and $1.95 \times 10^{5} \mathrm{TCID}_{50} \mathrm{ml}^{-1}$, respectively. The protection efficiencies of the compounds on the viabilities of GCO and EPC cells were evaluated using the WST-8 Kit (Shanghai BestBio Biology) according to the manufacturer's protocol.

Briefly, cells were seeded in a 96 -well plate $\left(5 \times 10^{4}\right.$ cells per well) containing $200 \mu \mathrm{l}$ medium and placed in an incubator for about $24 \mathrm{~h}$ until cells reached approximately $90 \%$ confluence in each well. The medium in each well was then replaced with $100 \mu \mathrm{l}$ of $100 \mathrm{TCID}_{50}$ virus and replaced again after $2 \mathrm{~h}$ using isopyknic MEM basal medium (3\% FBS) containing Mor and Rib in a geometric dilution series with a common ratio of 2.51 covering concentration from 100 to $1 \mu \mathrm{g} \mathrm{ml}^{-1}$. In addition, a toxicity test of the 2 compounds was performed in a geometric dilution series with a common ratio of 0.5 covering compound concentrations from 1000 to $15.6 \mu \mathrm{g} \mathrm{ml}^{-1}$.

After $96 \mathrm{~h}$ of culture, the sample medium in each well was replaced by $190 \mu \mathrm{l} \mathrm{MEM}$ and $10 \mu \mathrm{l} \mathrm{WST-8}$ test solution, and then $2 \mathrm{~h}$ later, the 96-well plate was read on a multi well scanning spectrophotometer at an optical density (OD) of $450 \mathrm{~nm}$. The spectrophotometer was calibrated to zero absorbance using the same solution without cells. In a toxicity test of the compounds, the cell viabilities were calculated using an absorbance $(A)$ test: $A_{\text {test }} / A_{\text {control }} \times 100 \%$. Each treatment was carried out in triplicate. The half toxic concentration ( $\mathrm{TC}_{50}, 50 \%$ cell viability) and safe concentration ( $\mathrm{SC}_{95}, 95 \%$ cell viability) were calculated by using probit analyses (Finney 1971).

\section{Morphological effect of compounds for virus-infected cells}

GCO cells and EPC cells were seeded into 6-well culture plates for about $24 \mathrm{~h}$ and infected by 100 TCID $_{50}$ GCRV and GSIV for $2 \mathrm{~h}$, respectively. Samples were observed under an inverted microscope at 48 and $96 \mathrm{~h}$ post medication $\left(40 \mu \mathrm{g} \mathrm{ml}^{-1}\right)$. Virusinduced apoptosis and drug-treated anti-apoptosis in host cells were studied to determine the morphological changes in the nucleus and cytoplasm. Briefly, normal cells, virus-infected cells and compoundtreated $\left(40 \mu \mathrm{g} \mathrm{ml}^{-1}\right)$ cells were collected at $48 \mathrm{~h}$ and stained using $1 \mu \mathrm{g} \mathrm{ml}^{-1}$ DAPI and $3.74 \mathrm{mg} \mathrm{ml}^{-1} 1,1^{\prime}$ dioctadecyl-3, 3, 3', 3'-tetramethylindocarbocyanine (Dil) for $20 \mathrm{~min}$, with phosphate-buffered saline cleaning 3 times in each step. These were mounted on glass slides and observed with an upright fluorescence microscopy (Leica-DM5000).

\section{Antiviral efficiency of Mor and Rib}

The antiviral efficiencies of compounds on the virus-infected cells were determined by the $\mathrm{TCID}_{50}$ method. Identical methods of cell culture and virus infection were used for antiviral assay. Each well of a 96 -well plate was seeded with $5 \times 10^{4}$ cells in $200 \mu \mathrm{l}$ medium and incubated in a biochemical incubator for about $24 \mathrm{~h}$ under the appropriate conditions. The medium in each well was then replaced with $100 \mu \mathrm{l}$ of 100 TCID $_{50}$ virus and replaced again after $2 \mathrm{~h}$ using isopyknic basal medium (3\% FBS) containing $20 \mu \mathrm{g} \mathrm{ml}^{-1}$ Mor or Rib. Viral titres of GCRV and GSIV were determined by the standard TCID $_{50}$ method, as described previously (Yu et al. 2014). All samples were prepared in triplicate.

\section{Sample collection, RNA extraction and reverse transcription}

The virus titer curve cannot be obtained when a $40 \mu \mathrm{g} \mathrm{ml}^{-1}$ drug concentration is used, because the drugs significantly inhibit the viruses. We found the $96 \mathrm{~h}$ titer of GCRV and GSIV far below the $72 \mathrm{~h}$ titer in a preliminary experiment, suggesting that the proliferation of viruses was restricted in the last phase of apoptosis. Therefore, the viral gene expressions and virus titer were detected at $12,24,48$, and $72 \mathrm{~h}$ after medication with $20 \mu \mathrm{g} \mathrm{ml}^{-1}$ Mor and Rib, respectively. Total RNA was extracted from respective virus-infected GCO and EPC cells using TRIzon Reagent (CWBIO) applied according to the kit instructions. The concentration of the RNA in samples were tested on a $1.5 \%$ agarose gel, and RNA samples with $\mathrm{OD}_{260 \mathrm{~nm}} / \mathrm{OD}_{280 \mathrm{~nm}}$ ratios between 1.8 and 2.0 were stored at $-80^{\circ} \mathrm{C}$ until use. All the samples had RNA concentrations greater than $600 \mathrm{ng}$ $\mathrm{\mu l}^{-1}$. First-strand complementary DNA was synthesized by using $3.25 \mu \mathrm{l}$ of total RNA and the PrimeScript RT reagent Kit (TaKaRa) that uses oligo dT primers and PrimeScript RT enzyme mix I. Samples were incubated for $15 \mathrm{~min}$ at $37^{\circ} \mathrm{C}$ followed by $5 \mathrm{~s}$ at 
$85^{\circ} \mathrm{C}$. The resulting first-strand complementary DNA was stored at $-80^{\circ} \mathrm{C}$.

\section{Quantitative real-time PCR (qRT-PCR)}

The qRT-PCR method was used to quantify the mRNA of viral gene expression. All the qRT-PCR reactions were performed using a Bio-Rad icycler IQ5 Real-time PCR Detection System (Bio-Rad) and an UltraSYBR Mixture (Cwbio). The complementary DNA was used as a template for qPCR with primer designed for particular genes (Table 1), and $\beta$-actin was used as a housekeeping gene to normalize gene expression studies. A $13 \mu \mathrm{l}$ set-up was used: $1 \mu \mathrm{l}$ of cDNA sample, $4.5 \mu \mathrm{l}$ nuclease-free water, $6.5 \mu \mathrm{l}$ of SYBR Green PCR master mix, and $0.5 \mu \mathrm{l}$ of each gene-specific primer $(10 \mu \mathrm{M})$. The cycling conditions were $95^{\circ} \mathrm{C}$ for $10 \mathrm{~min}$ followed by 40 cycles of $94^{\circ} \mathrm{C}$ for $15 \mathrm{~s}, 60^{\circ} \mathrm{C}$ for $30 \mathrm{~s}$ and $72^{\circ} \mathrm{C}$ for $30 \mathrm{~s}$. The threshold cycle $(C \mathrm{~T})$ value was determined using the IQ5 Sequence Detection System and exported into a Microsoft Excel Sheet for subsequent data analyses where the fold changes of gene expressions were calculated by $2^{-\triangle \Delta C T}$ method (Livak \& Schmittgen 2001).

\section{Data analysis}

The results were expressed as the mean \pm standard deviation (SD), and all data analyses were done using SPSS 16.0 software (SPSS). The least significant difference (LSD) test was used for betweengroup comparisons in the entire gene expression validations, viral titers and cell viability assay. The differences were determined by 1-way ANOVA with p-values less than 0.05 and 0.01 being considered as different significance levels.

Table 1. Primers used for the analysis of mRNA expression by qRT-PCR

\begin{tabular}{|c|c|c|c|}
\hline Gene & $\begin{array}{l}\text { GenBank } \\
\text { acc. no. }\end{array}$ & Primer sequence $\left(5^{\prime}-3^{\prime}\right)$ & $\begin{array}{l}\text { Product } \\
\text { size (bp) }\end{array}$ \\
\hline VP1 & JN967629 & $\begin{array}{l}\text { Fwd: TCAGTCGTCGGATAGGAGGC } \\
\text { Rev: CGATTGGTCCCAGAACGAGA }\end{array}$ & 84 \\
\hline $\begin{array}{l}\beta \text {-actin } \\
\quad(\text { grass carp) }\end{array}$ & M25013 & $\begin{array}{l}\text { Fwd: GATGATGAAATTGCCGCACTG } \\
\text { Rev: ACCGACCATGACGCCCTGATGT }\end{array}$ & 135 \\
\hline $\mathrm{MCP}$ & FJ358611 & $\begin{array}{l}\text { Fwd: GCGGTTCTCACACGCAGTC } \\
\text { Rev: ACGGGAGTGACGCAGGTGT }\end{array}$ & 93 \\
\hline $\begin{array}{l}\beta \text {-actin } \\
\text { (common ca }\end{array}$ & $\begin{array}{l}\text { M24113 } \\
\text { rp) }\end{array}$ & $\begin{array}{l}\text { Fwd: AGACATCAGGGTGTCATGGTTGGT } \\
\text { Rev: CTCAAACATGATCTGTGTCAT }\end{array}$ & 352 \\
\hline
\end{tabular}

\section{RESULTS}

\section{Protective efficiency of compounds against GCRV and GSIV}

In the screening test, $100 \mu \mathrm{g} \mathrm{ml}^{-1}$ of Mor and Rib exhibited more than $80 \%$ protective efficiency to GCRV- and GSIV-infected host cells (Fig. 1A). However, the compounds showed no obvious activity against SVCV (less than 15\%). Under the condition of $100 \mathrm{TCID}_{50} \mathrm{ml}^{-1}$ viral infections, GCO cells and EPC cells exposed to Mor and Rib showed concentration- and time-dependent induction of cell viability (Fig. 1B). The 2 compounds showed a positive protective efficiency after medication. Briefly, Mor prevented over $40 \%$ apoptosis in virus-infected GCO cells and EPC cells at $6.3 \mu \mathrm{g} \mathrm{ml}^{-1}$, which is better than the same concentration of Rib (less than 25\% apoptosis). Moreover, cell viabilities of the Mor-treated GCO cells and Rib-treated EPC cells demonstrate no significant decrease at $100 \mu \mathrm{g} \mathrm{ml}^{-1}$. When virusinfected cells were exposed to $100 \mu \mathrm{g} \mathrm{ml}^{-1}$ of Mor for $96 \mathrm{~h}$, the cell viability of the EPC cells (74.55 \pm $3.82 \%$ ) was less than that of the GCO cells (100.43 \pm $0.64 \%$ ). The same concentration of Rib also offered excellent protection to GCRV-infected GCO cells $(90.97 \pm 1.49 \%)$ and GSIV-infected EPC cells $(100.03 \pm 1.88 \%)$. In addition, cell viabilities of all the virus-infected cells were found to have more than a $95 \%$ reduction within $96 \mathrm{~h}$.

\section{Cytotoxicity of compounds in GCO cells and EPC cells}

Under experimental conditions, the cytotoxicity of Mor was lower than Rib, as shown in Fig. 2. No significant decrease in cell viability was observed at $96 \mathrm{~h}$ until the concentration of compounds increased to $250 \mu \mathrm{g} \mathrm{ml}^{-1}$ in GCO cells and to $125 \mu \mathrm{g} \mathrm{ml}^{-1}$ in EPC cells. At the same concentration of compounds, cell viabilities of Mortreated GCO cells and EPC cells were equal or greater than those of the Rib-treated cells. The $\mathrm{TC}_{50}(660.3 \pm 12.4 \mu \mathrm{g}$ $\left.\mathrm{ml}^{-1}\right)$ and $\mathrm{SC}(96.1 \pm 16.0 \mu \mathrm{g}$ $\mathrm{ml}^{-1}$ ) of Rib at $96 \mathrm{~h}$ are lower than Mor $\left(\mathrm{TC}_{50}, 1117.2 \pm\right.$ $23.5 \mu \mathrm{g} \mathrm{ml} \mathrm{m}^{-1}$; $\mathrm{SC}, 140.9 \pm$ $25.7 \mu \mathrm{g} \mathrm{ml}^{-1}$ ) in the $\mathrm{GCO}$ cells. Similarly, the $96 \mathrm{~h} \quad \mathrm{TC}_{50}$ 


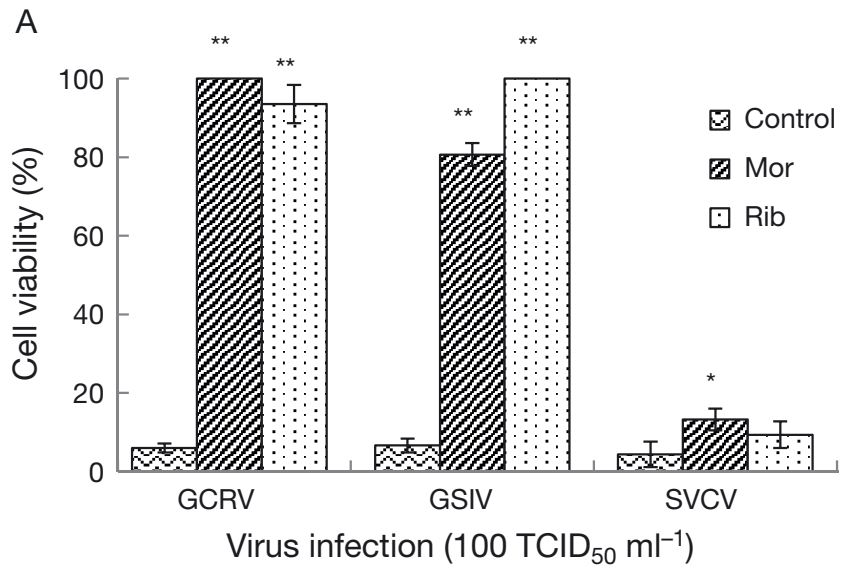

Fig. 1. Protective efficiency of moroxydine hydrochloride (Mor) and ribavirin (Rib) against different viruses in vitro. (A) The 96 $\mathrm{h}$ screening test of compounds against grass carp reovirus (GCRV), giant salamander iridovirus (GSIV) and spring viraemia of carp virus (SVCV) in vitro. Data are means \pm SD. ${ }^{*} \mathrm{p}<0.05 ;{ }^{* *} \mathrm{p}<0.01$. TCID $_{50}: 50 \%$ tissue culture infective dose. (B) Protective efficiency of compounds against GCRV and GSIV at different concentrations and times. GCO: grass carp ovary; EPC: epithelioma papulosum cyprinid

B

Mor-GCRV-GCO
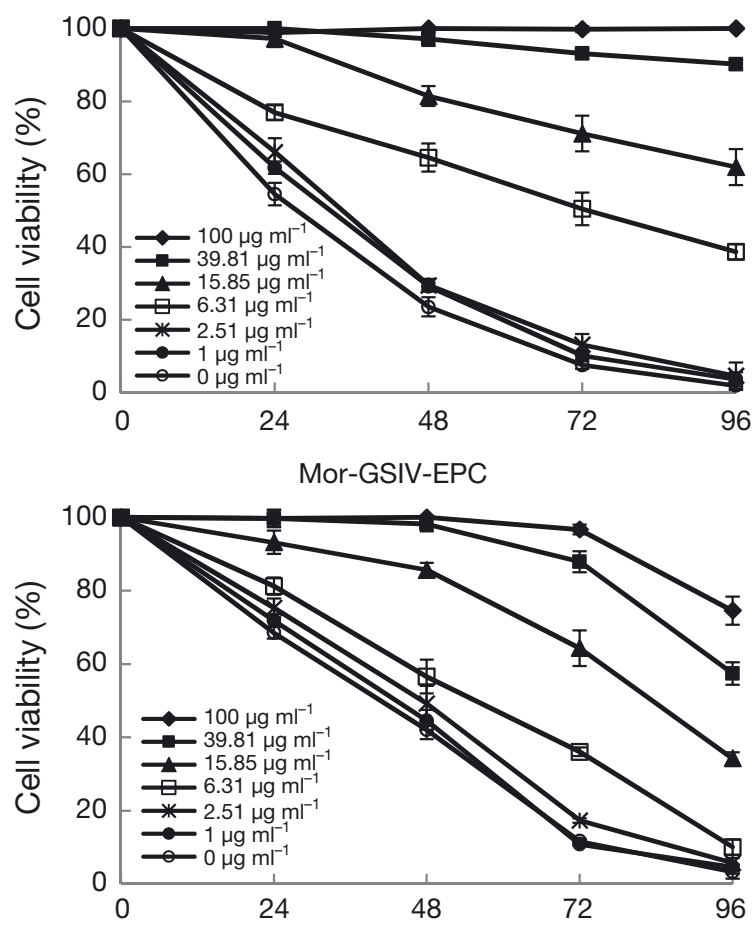

Rib-GCRV-GCO
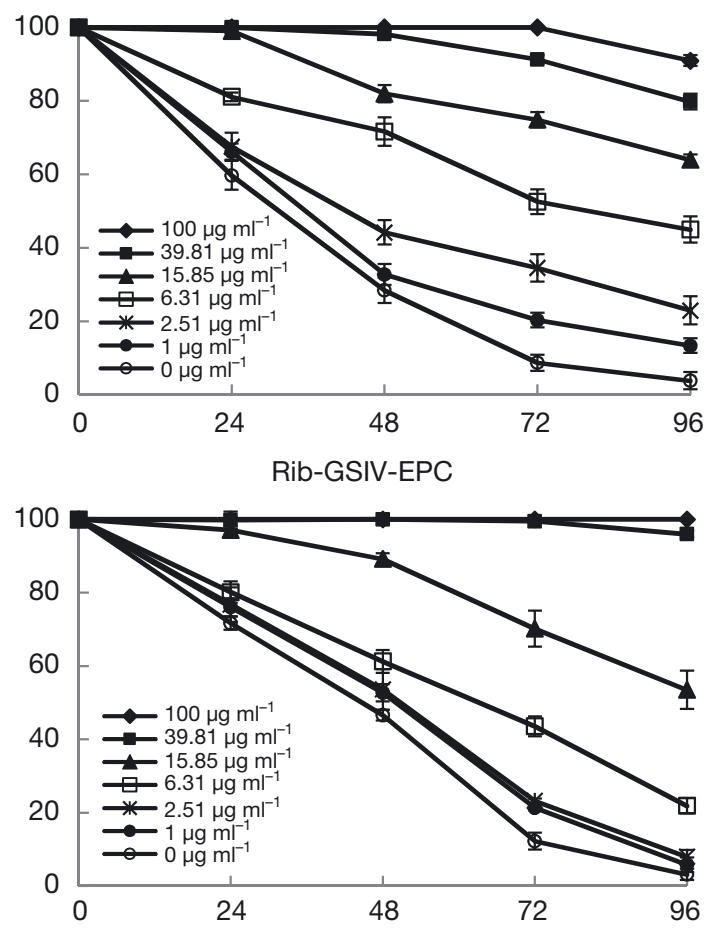

Time (h) post-infection

$\left(1162.1 \pm 9.7 \mu \mathrm{g} \mathrm{ml}^{-1}\right)$ and $\mathrm{SC}\left(154.8 \pm 16.8 \mu \mathrm{g} \mathrm{ml}^{-1}\right)$ of Rib are less than Mor $\left(\mathrm{TC}_{50}, 1486.3 \pm 24.0 \mu \mathrm{g} \mathrm{ml}^{-1}\right.$; $\mathrm{SC}, 209.7 \pm 17.4 \mathrm{\mu g} \mathrm{ml}^{-1}$ ) in the EPC cells.

\section{Morphological effect of compounds against GCRV and GSIV}

Cytopathic effect (CPE) and cell death were observed in virus-infected GCO and EPC cells under an inverted microscope at 48 and $96 \mathrm{~h}$ (Fig. 3). Severe $\mathrm{CPE}$ appeared in GCO cells at $48 \mathrm{~h}$ post infection with
100 TCID $_{50}$ GCRV (Fig. 3A). The control cells maintained the normal growth state without any CPE or cell death. GCRV-induced CPE and cell death were effectively reduced in Mor- and Rib-treated GCO cells. In EPC cells, the GSIV-induced CPE was observed at $48 \mathrm{~h}$, and severe CPE appeared at $96 \mathrm{~h}$. These CPE and cell deaths were effectively inhibited in Mor- and Rib-treated EPC cells. Moreover, Rib was found more effective than Mor in the treatment of GSIV because CPE appeared in the Mor-treated EPC cells at $96 \mathrm{~h}$. Thus, both Mor and Rib played an important role in controlling apoptosis induced by in this study. 

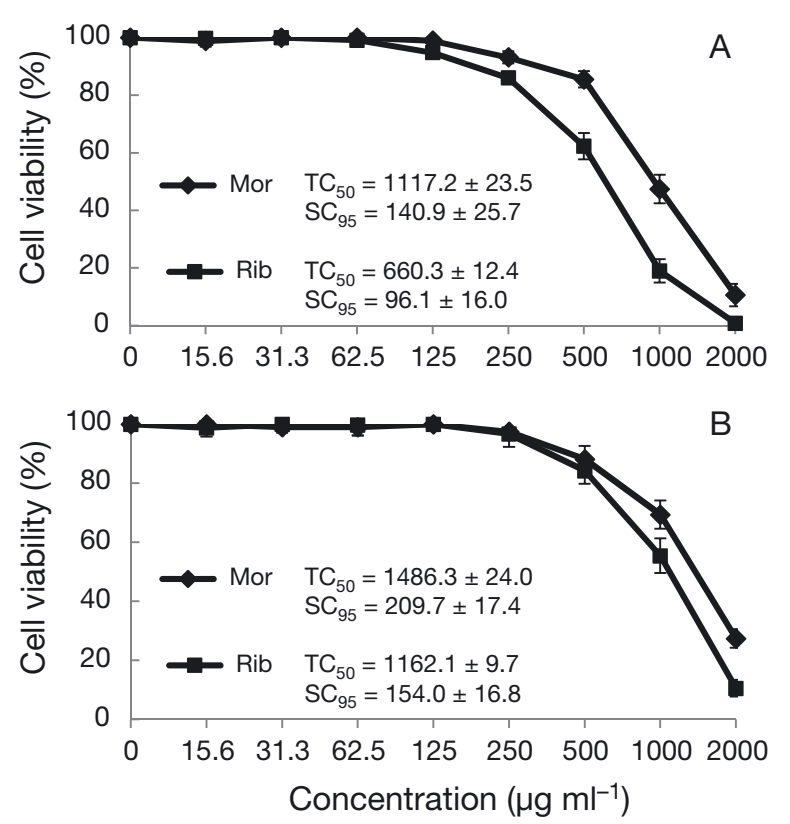

Fig. 2. Cytotoxicity of moroxydine hydrochloride (Mor) and ribavirin (Rib) in (A) grass carp ovary and (B) epithelioma papulosum cyprinid cells at $96 \mathrm{~h}$ post treatment. All data are means $\pm \mathrm{SD}$. Toxic $\left(\mathrm{TC}_{50} ; 50 \%\right.$ cell viability) and safe $\left(\mathrm{SC}_{95 i}\right.$ $95 \%$ cell viability) were calculated using probit analyses

\section{Anti-apoptosis effects of compounds on the viruses-infected host cells}

The GCRV-infected GCO cells and GSIV-infected EPC cells showed typical apoptotic features at $48 \mathrm{~h}$, including nuclear and cytoplasmic degradation (Fig. 4). Mor and Rib provided significant protection to the virus-infected cells so that they could keep their normal morphology and cellular structure, as indicated in Fig. 4. Therefore, Mor and Rib could help infected cells maintain their normal morphology and structure and prevent the nuclear and cytoplasmic dissolution of the GCRV-infected cells.

\section{Antiviral efficiency of Mor and Rib against GCRV and GSIV}

The virus titers of GCRV and GSIV were calculated using the standard TCID ${ }_{50}$ method. Following the initial infection conditions of $100 \mathrm{TCID}_{50} \mathrm{ml}^{-1}$ for $2 \mathrm{~h}$, the virulence of GCRV and GSIV in respective host cells showed a time-dependent increase from 12 to $72 \mathrm{~h}$ (Fig. 5). Mor and Rib significantly inhibited virulence of GCRV and GSIV compared to the respective control group, and the virus titer in each treatment showed a time-dependent increase. The lower virus level (ln value less than 2) could not be detected. Meanwhile, Mor and Rib presented a consistent antiviral activity when the treatment concentration was $20 \mu \mathrm{g} \mathrm{ml}^{-1}$.

\section{Effects of compounds on the expression of viral genes}

Virus-infected cells exposed to Mor or Rib (20 $\mu \mathrm{g}$ $\mathrm{ml}^{-1}$ ) showed a significant inhibition of viral gene expression (Fig. 6). In GCRV-infected GCO cells, expressions of all viral genes were significantly suppressed at all time points post medication. In particular, VP1 expression in Mor-treated GCO cells were significantly less than in Rib-treated cells at 36 and $48 \mathrm{~h}$, which suggested that Mor had better antiviral activity than Rib in the treatment of GCRV. Our study also found that MCP gene expression in Mor- and Rib-treated cells were inhibited at all detected times. In GSIV-infected EPC cells, Mor and Rib showed no significant difference, and the relative expressions of the MCP gene were less than 0.5 at all detected times. Briefly, Mor and Rib presented a continuous antiviral activity post medication at $20 \mu \mathrm{g} \mathrm{ml}^{-1}$.

\section{DISCUSSION}

Aquatic virus infections directly influence the aquaculture industry and have attracted much attention in recent years because these pathogens cause severe disease in aquatic animals. Consequently, controlling aquareovirus and iridovirus has become more important in aquaculture, and some studies have made advances in viral characterization (Kim et al. 2004, Williams et al. 2004). GCRV is the most pathogenic aquareovirus and to some extent has been suppressed by vaccine administration, immunoregulation or pharmacologic inhibition (Rangel et al. 1999, Samanta et al. 2013, Xue et al. 2013, Yu et al. 2014). GSIV can cause severe hemorrhagic disease in wild and farmed giant salamander (Williams et al. 2005). Moreover, this virus can induce the EPC cell lesion effect, and in some correlational research (Ma et al. 2014) its ultrastructure and morphogenesis was studied. However, it is still difficult to control GCRV and GSIV infection at present. One of the reasons for this is that there is no effective drug for use. Moreover, immunoregulation and vaccine administration is not enough to reduce the high mortality caused by many aquatic viral diseases, because the subtype specificity of vaccines show a relatively narrow anti- 


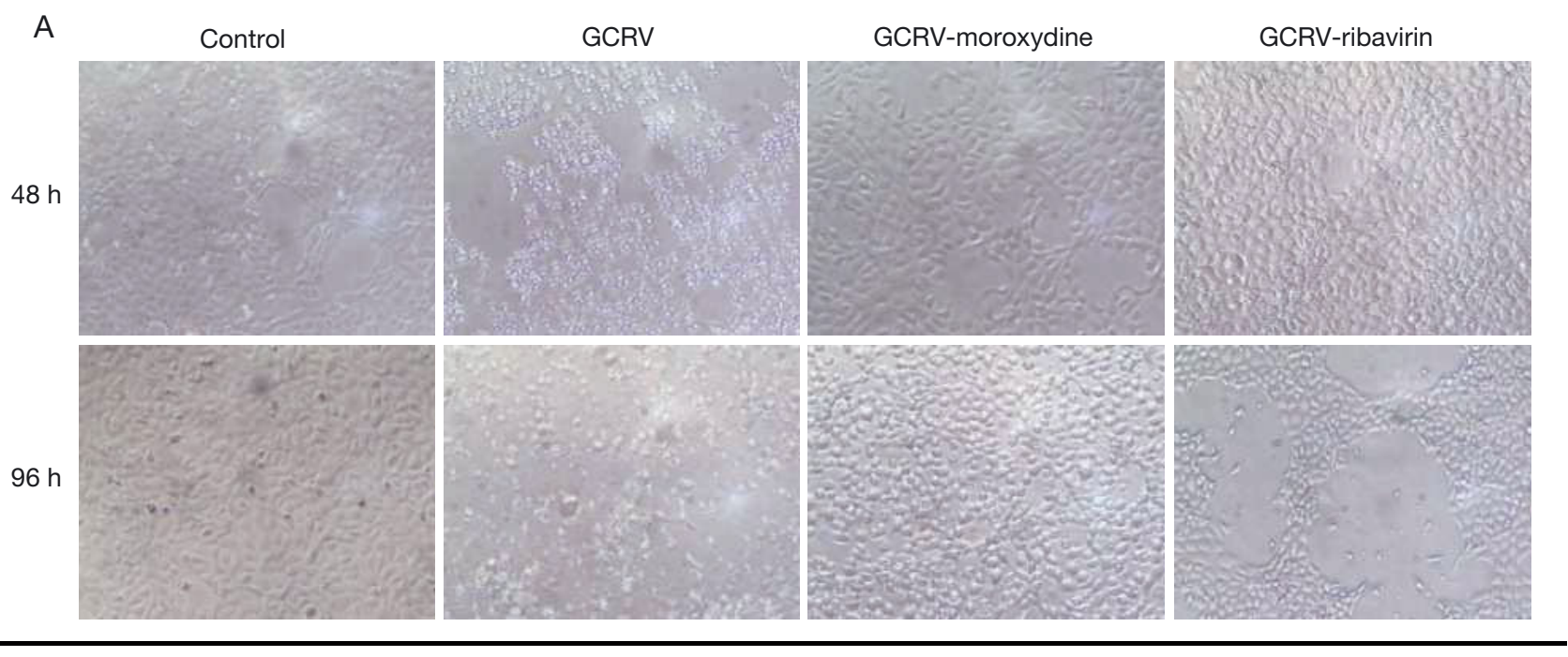

B
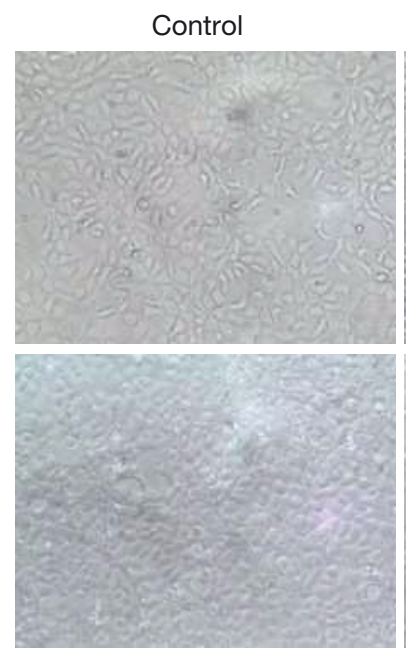

GSIV
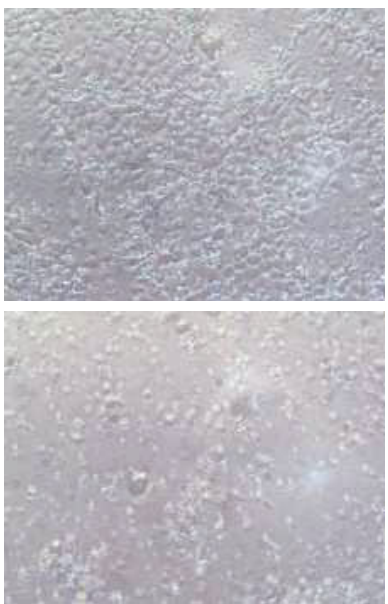

GSIV-moroxydine
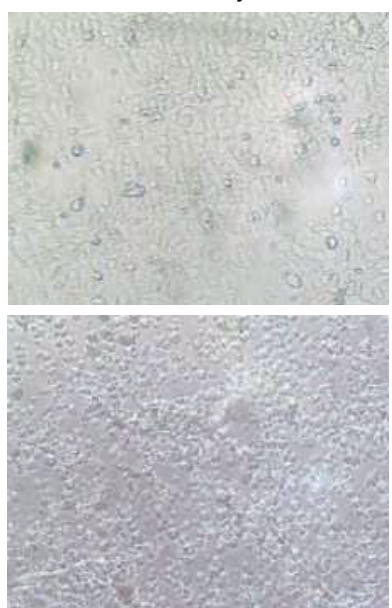

GSIV-ribavirin

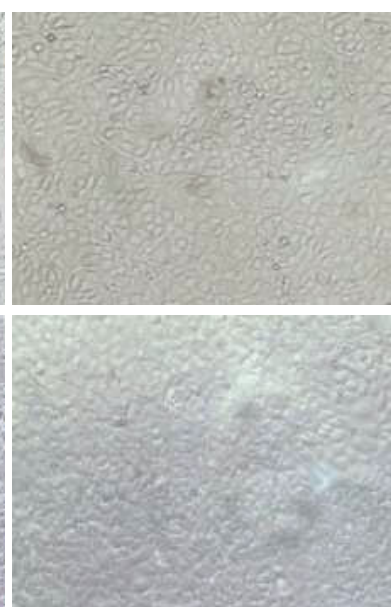

Fig. 3. Morphological effect of compounds $\left(40 \mu \mathrm{g} \mathrm{ml}^{-1}\right)$ on virus-infected $(100 \times 50 \%$ tissue culture infective dose) (A) grass carp ovary and (B) epithelioma papulosum cyprinid cells. GCRV: grass carp reovirus; GSIV: giant salamander iridovirus

viral spectrum, and the complexity of the immune response which determines immunoregulation needs further research and development (Hammond et al. 1999, Citarasu, 2010). Therefore, the addition of an antiviral agent may lead to effective improvements in controlling virus pathogenicity (Feld \& Hoofnagle 2005).

Mor was first developed in the 1950s and has been shown to have a number of antiviral efficacies against various human DNA and RNA viruses (Sheppard 1994, Gasparini et al. 2014, Magri et al. 2015), but its antiviral effects and pharmacological mechanisms have rarely been reported in aquaculture. It therefore is an antiviral substance which needs to be more fully studied and utilized in aquaculture. Likewise, Rib as an antiviral agent has many antiviral activities in the treatment of a number of aquatic viruses including rainbow trout rhabdovirus (Marroquí et al. 2007), GCRV (Zhu et al. 2015), and chum salmon reovirus (DeWitte-Orr \& Bols 2007). Therefore, the broad-spectrum antiviral agent Rib was used as a positive control for a screening test against GCRV, SVCV and GSIV. The screening results showed that Mor and Rib can effectively control GCRV- and GSIV-induced cell apoptosis in vitro.

GCRV (dsRNA virus) and GSIV (large DNA virus) can cause systemic hemorrhagic disease in different aquatic animals and have been used as models for research (Rangel et al. 1999, Gao et al. 2012). Grass carp is the largest freshwater aquaculture species in China in terms of biomass production, and fish farm- 


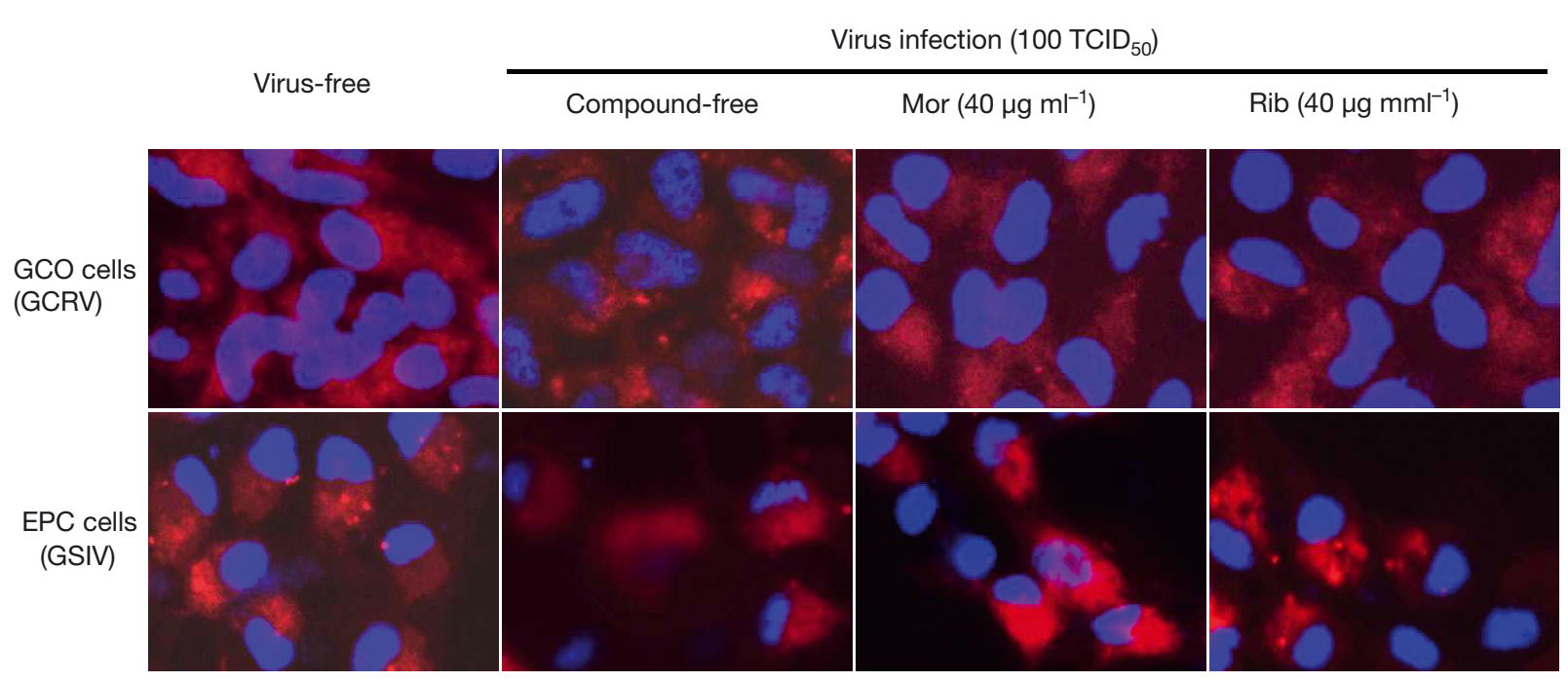

Fig. 4. Virus-induced apoptosis and the anti-apoptosis efficacy of moroxydine hydrochloride (Mor) and ribavirin (Rib) on virusinfected cells $48 \mathrm{~h}$ after infection. TCID 50 : tissue culture infective dose 50\%; GCO: grass carp ovary; EPC: epithelioma papulosum cyprinid; GCRV: grass carp reovirus; GSIV: giant salamander iridovirus

A

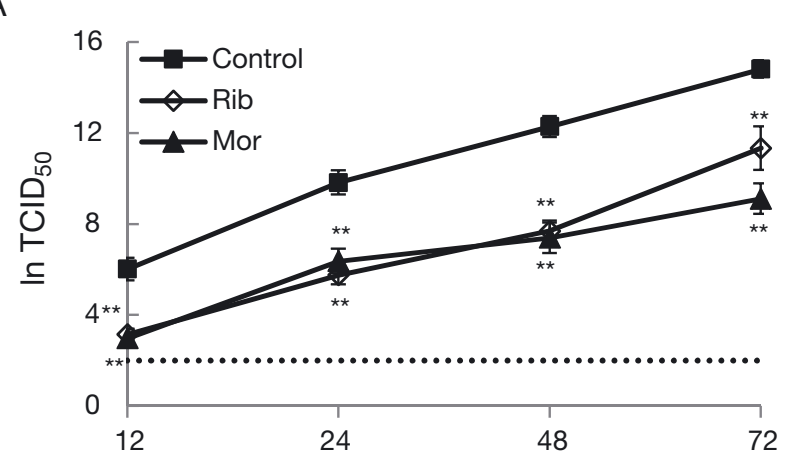

B

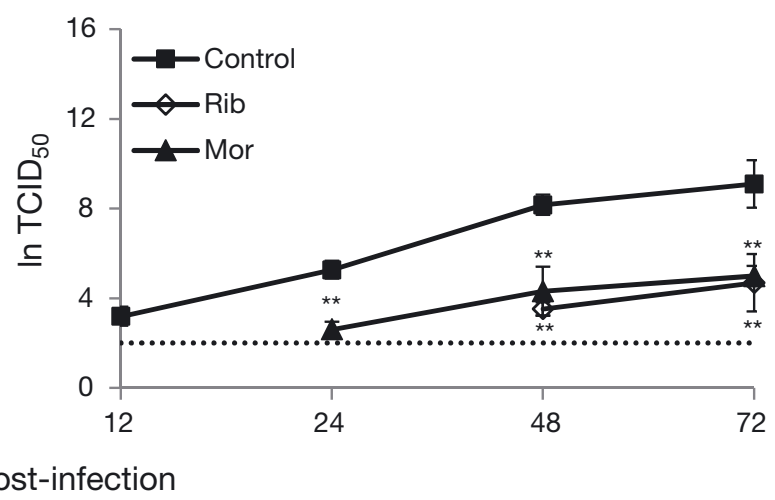

Fig. 5. Antiviral activity of moroxydine hydrochloride (Mor) and ribavirin (Rib) against (A) grass carp reovirus and (B) giant salamander iridovirus in respective host cells. TCID $_{50}: 50 \%$ tissue culture infective dose. Data are means \pm SD. ${ }^{* *} \mathrm{p}<0.05$. Dotted lines represent the detection threshold $\left(\operatorname{lnTCID}{ }_{50} \leq 2\right)$

ing is of significance in providing food protein for human beings (Wu et al. 2012). GCRV, known as the most pathogenic aquareovirus in the last $30 \mathrm{yr}$, causes severe hemorrhagic disease with almost $85 \%$ mortality in fingerling and yearling populations of grass carp (Q. Wang et al. 2012). The giant salamander is one of the world's largest amphibian species, and it was listed as a Class II protected animal in China. However, authorities have allowed farmed second filial generation giant salamander to be used as food for human beings in this country due to an increasing population of these salamanders. GSIV was frequently reported in farmed Chinese giant salamanders in recent years, and it causes pathologic changes causing up to $95 \%$ of mortality in major population areas including in Shaanxi, Sichuan, and Henan Province (Dong et al. 2011, Geng et al. 2011). However, there is a shortage of potent antiviral agents and lack of research on how to control GCRV and GSIV. For our study, GCRV-infected GCO cells and GSIV-infected EPC cells appeared to have a typical CPE within 96 h. The GCRV 104 virus strain was isolated from diseased grass carp in 2009, and the gene sequence contains 11 segments encoding 12 proteins (Fan et al. 2013). Among them, the conserved domain VP1 belonged to the reovirus L2 superfamily and was predicted to encode the guanylyl transferase protein with putative functions as an 

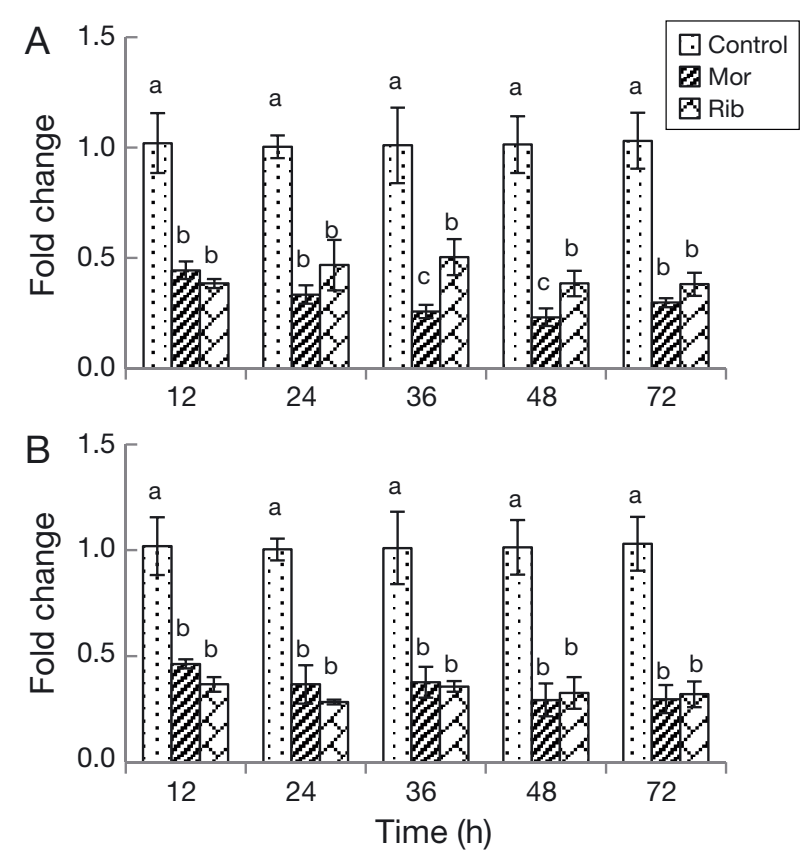

Fig. 6. Effects of antiviral compounds on viral protein gene expression in (A) grass carp reovirus-infected grass carp ovary cells and (B) giant salamander iridovirus-infected epithelioma papulosum cyprinid cells. Data are means $\pm \mathrm{SD}$; different letters represent significant differences between treatment groups at each timepoint $(p<0.05)$. Mor: moroxydine hydrochloride; Rib: ribavirin

mRNA capping enzyme (Fan et al. 2013). The GSIV strain has been isolated from Chinese giant salamander Andrias davidianus, and the MCP has been used for viral quantification (Zhao et al. 2007, Meng et al. 2013). The MCP is the major structural component of iridovirus particles, accounting for up to $45 \%$ of all virus proteins and is required for the assembly and release of virus progeny (Tidona et al. 1998, Hyatt et al. 2000). The conserved MCP coding regions successfully amplified from 9 iridovirus isolates and the expression levels correlate with viral production; this suggests that the MCP may be the key to developing PCR assays for iridovirus identification (Mao et al. 1997, Zhao et al. 2007). In this study, the MCP gene expression in GSIV-infected EPC cells and the VP1 gene expression in GCRV-infected GCO cells were found significantly inhibited after medication with Mor or Rib.

To measure cytotoxicity and antiviral activity, the WST-8 assay (which depends on the conversion of tetrazolium salt WST-8 to highly water-soluble formazan by viable cells) was used to measure changes in cell viability. It is a perfect method for use in cell viability assays and has been widely utilized in drug sensitivity tests (Tominaga et al. 1999, Yamawaki \&
Iwai 2006). The amount of produced formazan was determined with a spectrophotometer at $450 \mathrm{~nm}$ and is directly proportional to the number of living cells (Tominaga et al. 1999). The SC values of Mor and Rib indicated that compounds are safe for GCO and EPC cells up to $96 \mu \mathrm{g} \mathrm{ml}^{-1}$, making it possible to rule out a toxic influence on antiviral activity assays. Therefore, the cell viability in antiviral activity assays directly reflects the protective activity of the compounds. Results of this study confirmed that virus-infected cells exposed to Mor and Rib result in different degrees of protection of cell viability. The results also indicate that Mor and Rib had a better in vivo antiGCRV activity than herbal medicines or isolated chemicals (Yu et al. 2014).

The emergence of deadly iridovirus diseases in aquatic animals has led to a growing interest in the mechanisms of iridovirus-induced host cell death (Imajoh et al. 2004, Pham et al. 2012, Chen et al. 2016). Most iridoviruses induce typical apoptosis or trigger non-apoptotic-programmed cell death in fish cells (Gibson-Kueh et al. 2003, Chen et al. 2016). A similar phenomenon appeared in the GCRV-infected cells, and some studies suggested that the trigger of apoptosis and oxidative stress might be associated with the death receptor pathway. In this study, 3 aquatic viruses were propagated in respective host cells with a typical CPE. More importantly, Mor and Rib as broad-spectrum antiviral agents exhibited prominent morphological protection to different virus-infected GCO and EPC cells. Due to the direct inhibitory effect of compounds on virion replication, GCRV- and GSIV-induced CPE and cell death in respective host cells was effectively blocked, which contributed to the maintanence of the normal growth situation and intact cell structure.

In this study, GCO and EPC cells showed differential CPEs after inoculation of GCRV, SVCV or GSIV and were indicative of high sensitivities to respective viruses. Similar results appeared in other research which determined that the isolated Pseudobagrus ussuriensis skin cell line showed differential CPEs after inoculation of SVCV, GCRV and Rana grylio virus (Ou et al. 2014). In addition, the virus titers of GCRV and GSIV were significantly inhibited after medication with a low concentration of Mor or Rib.

In summary, Mor and Rib as broad-spectrum agents exhibit excellent antiviral activity and show low cytotoxicity to GCRV-infected GCO cells and GSIV-infected EPC cells. This study demonstrates that exposure of virus-infected cells to antiviral compounds could inhibit the virus replication, CPE and apoptosis and help cells maintain a normal morpho- 
logical structure. Therefore, Mor and Rib are regarded as antiviral agents exhibiting high antiGCRV and anti-GSIV activity and have proved to be appropriate inhibitors for controlling virus in aquaculture.

Acknowledgements. The authors thank Prof. Ling-Bing Zeng at the Yangtze River Fisheries Research Institute of China for kindly providing cells and virus strains. This research was supported by the 'Water Conservancy Science and Technology Project of Shaanxi Province, China (No. 2016slkj-18)' and 'The Fundamental Research Funds for the Central Universities of the ministry of Education, China (No. 2452015255)'.

\section{LITERATURE CITED}

Attoui H, Attoui H, Fang Q, Jaafar FM, and others (2002) Common evolutionary origin of aquareoviruses and orthoreoviruses revealed by genome characterization of Golden shiner reovirus, grass carp reovirus, striped bass reovirus and golden ide reovirus (genus Aquareovirus, family Reoviridae). J Gen Virol 83:1941-1951

Björklund HV, Emmenegger EJ, Kurath G (1995) Comparison of the polymerases (L genes) of spring viremia of carp virus and infectious hematopoietic necrosis virus. Vet Res 26:394-398

> Chan JFW, Chan KH, Kao RYT, To KK, and others (2013) Broad-spectrum antivirals for the emerging Middle East respiratory syndrome coronavirus. J Infect 67:606-616

Chen X, Wang Q, Yang C, Rao Y, and others (2013) Identification, expression profiling of a grass carp TLR8 and its inhibition leading to the resistance to reovirus in CIK cells. Dev Comp Immunol 41:82-93

> Chen XY, Wen CM, Wu JL, Su YC, Hong JR (2016) Giant seaperch iridovirus (GSIV) induces mitochondria-mediated cell death that is suppressed by bongkrekic acid and cycloheximide in a fish cell line. Virus Res 213:37-45

Chinchar VG, Essbayer S, He JG, Hyatt A, Miyazaki T, Seligy V, Williams T (2005) Family Iridoviridae. In: Fauquet CM, Mayo, MA, Maniloff J, Desselberger U, Ball LA (eds) Virus taxonomy, 8th edn. Elsevier Academic Press, San Diego, CA, p 162-163

Citarasu T (2010) Herbal biomedicines: a new opportunity for aquaculture industry. Aquacult Int 18:403-414

Daszak P, Berger L, Cunningham AA, Hyatt AD, Green DE, Speare R (1999) Emerging infectious diseases and amphibian population declines. Emerg Infect Dis 5: 735-748

> DeWitte-Orr SJ, Bols NC (2007) Cytopathic effects of chum salmon reovirus to salmonid epithelial, fibroblast and macrophage cell lines. Virus Res 126:159-171

> Dong W, Zhang X, Yang C, An J, Qin J, Song F, Zeng W (2011) Iridovirus infection in Chinese giant salamanders, China, 2010. Emerg Infect Dis 17:2388-2389

Fan Y, Rao S, Zeng L, Ma J, Zhou Y, Xu J, Zhang H (2013) Identification and genomic characterization of a novel fish reovirus, Hubei grass carp disease reovirus, isolated in 2009 in China. J Gen Virol 94:2266-2277

Feld JJ, Hoofnagel JH (2005) Mechanism of action of interferon and ribavirin in treatment of hepatitis C. Nature 436:967-972
Finney DJ (1971) Probit analysis, 3rd edn. Cambridge University Press, Cambridge

Gao ZY, Zeng LB, Xiao HB, Zhang H, Meng Y, Xiao Y, Xu J (2012) Studies on the physical, chemical and biological characteristics of giant salamander iridovirus. Freshw Fish 42:17-26

> Gasparini R, Amicizia D, Lai PL, Bragazzi NL, Panatto D (2014) Compounds with anti-influenza activity: present and future of strategies for the optimal treatment and management of influenza. Part II. Future compounds against influenza virus. J Prev Med Hyg 55:109-129

> Geng Y, Wang KY, Zhou ZY, Li CW, and others (2011) First report of a ranavirus associated with morbidity and mortality in farmed Chinese giant salamanders (Andrias davidianus). J Comp Pathol 145:95-102

Gibson-Kueh S, Netto P, Ngoh-Lim GH, Chang SF, and others (2003) The pathology of systemic iridoviral disease in fish. J Comp Pathol 129:111-119

> Hammond SA, Raabe ML, Issel CJ, Montelaro RC (1999) Evaluation of antibody parameters as potential correlates of protection or enhancement by experimental vaccines to equine infectious anemia virus. Virology 262:416-430

> He Y, Xu H, Yang Q, Xu D, Lu L (2011) The use of an in vitro microneutralization assay to evaluate the potential of recombinant VP5 protein as an antigen for vaccinating against grass carp reovirus. Virol J 8:132-138

Holopainen R, Ohlemeyer S, Schütze H, Bergmann SM, Tapiovaara H (2009) Ranavirus phylogeny and differentiation based on major capsid protein, DNA polymerase and neurofilament triplet H1-like protein genes. Dis Aquat Org 85:81-91

Hudson JB, Graham EA, Simpson MF (1988) The efficacy of amantadine and other antiviral compounds against two salmonid viruses in vitro. Antiviral Res 9:379-385

> Hyatt AD, Gould AR, Zupanovic Z, Cunningham AA, and others (2000) Comparative studies of piscine and amphibian iridoviruses. Arch Virol 145:301-331

> Imajoh M, Sugiura H, Oshima S (2004) Morphological changes contribute to apoptotic cell death and are affected by caspase- 3 and caspase- 6 inhibitors during red sea bream iridovirus permissive replication. Virology 322:220-230

- Kamar N, Rostaing L, Abravanel F, Garrouste C, and others (2010) Ribavirin therapy inhibits viral replication on patients with chronic hepatitis E virus infection. Gastroenterology 139:1612-1618

Ke F, He LB, Zhang QY (2013) Nonstructural protein NS80 is crucial in recruiting viral components to form aquareoviral factories. PLOS ONE 8:e63737

- Kim J, Tao Y, Reinisch KM, Harrison SC, Nibert ML (2004) Orthoreovirus and Aquareovirus core proteins: conserved enzymatic surfaces, but not protein-protein interfaces. Virus Res 101:15-28

Koutná M, Vesely T, Psikal I, Hulova J (2003) Identification of spring viraemia of carp virus (SVCV) by combined RTPCR and nested PCR. Dis Aquat Org 55:229-235

Leyssen P, Balzarini J, De Clercq E, Neyts J (2005) The predominant mechanism by which ribavirin exerts its antiviral activity in vitro against flaviviruses and paramyxoviruses is mediated by inhibition of IMP dehydrogenase. J Virol 79:1943-1947

Liu W, Xu J, Ma J, LaPatra SE, and others (2014) Immunological responses and protection in Chinese giant salamander Andrias davidianus immunized with inactivated iridovirus. Vet Microbiol 174:382-390 
Livak KJ, Schmittgen TD (2001) Analysis of relative gene expression data using realtime quantitative PCR and the $2^{-\Delta \Delta C \mathrm{~T}}$ method. Methods 25:402-408

Ma J, Zeng L, Zhou Y, Jiang N, and others (2014) Ultrastructural morphogenesis of an amphibian iridovirus isolated from Chinese giant salamander (Andrias davidianus). J Comp Pathol 150:325-331

- Magri A, Reilly R, Scalacci N, Radi M, and others (2015) Rethinking the old antiviral drug moroxydine: discovery of novel analogues as anti-hepatitis $\mathrm{C}$ virus (HCV) agents. Bioorg Med Chem Lett 25:5372-5376

Mao J, Hedrick RP, Chinchar VG (1997) Molecular characterization, sequence analysis, and taxonomic position of newly isolated fish iridoviruses. Virology 229:212-220

> Marroquí L, Estepa A, Perez L (2007) Assessment of the inhibitory effect of ribavirin on the rainbow trout rhabdovirus VHSV by real-time reverse-transcription PCR. Vet Microbiol 122:52-60

Meng Y, Zhang H, Liang H, Zeng L, Xiao H, Xie C (2013) Development of a loop-mediated isothermal amplification assay for rapid detection of iridovirus in the Chinese giant salamander. J Virol Methods 194:211-216

Ou T, Lei XY, He LB, Zhou FJ, Zhang QY (2014) Development of an Ussuri catfish Pseudobagrus ussuriensis skin cell line displaying differential cytopathic effects to three aquatic animal viruses. Virus Res 189:56-62

Padhi A, Verghese B (2012) Molecular evolutionary and epidemiological dynamics of a highly pathogenic fish rhabdovirus, the spring viremia of carp virus (SVCV). Vet Microbiol 156:54-63

Pham PH, Lai YS, Lee FF, Bols NC, Chiou PP (2012) Differential viral propagation and induction of apoptosis by grouper iridovirus (GIV) in cell lines from three nonhost species. Virus Res 167:16-25

Rangel AAC, Rockemann DD, Hetrick FM, Samal SK (1999) Identification of grass carp haemorrhage virus as a new genogroup of aquareovirus. J Gen Virol 80:2399-2402

Rowe T, Banner D, Farooqui A, Ng DC, and others (2010) In vivo ribavirin activity against severe pandemic H1N1 influenza A/Mexico/4108/2009. J Gen Virol 91: 2898-2906

Samanta M, Basu M, Swain B, Panda P, Jayasankar P (2013) Molecular cloning and characterization of toll-like receptor 3, and inductive expression analysis of type I IFN, Mx and pro-inflammatory cytokines in the Indian carp, rohu (Labeo rohita). Mol Biol Rep 40:225-235

Sheppard S (1994) Moroxydine: the story of a mislaid antiviral. Acta Derm Venereol Suppl 183:1-9

Editorial responsibility: James Jancovich, San Marcos, California, USA
Tidona CA, Schnitzler P, Kehm R, Darai G (1998) Is the major capsid protein of iridoviruses a suitable target for the study of viral evolution? Virus Genes 16:59-66

Tominaga H, Ishiyama M, Ohseto F, Sasamoto K, Hamamoto T, Suzuki K, Watanabe M (1999) A water-soluble tetrazolium salt useful for colorimetric cell viability assay. Anal Commun 36:47-50

Wang Q, Zeng W, Liu C, Zhang C, Wang Y, Shi C, Wu S (2012) Complete genome sequence of a reovirus isolated from grass carp, indicating different genotypes of GCRV in China. J Virol 86:12466

> Wang Z, Wei P, Wang L, Wang Q (2012) Design, synthesis, and anti-tobacco mosaic virus (TMV) activity of phenanthroindolizidines and their analogues. J Agric Food Chem 60:10212-10219

Williams T, Barbosa-Solomieu V, Chinchar VG (2005) A decade of advances in iridovirus research. Adv Virus Res 65:173-248

Wu S, Wang G, Angert ER, Wang W, Li W, Zou H (2012) Composition, diversity, and origin of the bacterial community in grass carp intestine. PLOS ONE 7:e30440

> Xue R, Liu L, Cao G, Xu S and others (2013) Oral vaccination of BacFish-vp6 against grass carp reovirus evoking antibody response in grass carp. Fish Shellfish Immunol 34: 348-355

Yamawaki H, Iwai N (2006) Cytotoxicity of water-soluble fullerene in vascular endothelial cells. Am J Physiol Cell Physiol 290:C1495-C1502

Yu XB, Liu GL, Zhu B, Hao K, Ling F, Wang GX (2014) In vitro immunocompetence of two compounds isolated from Polygala tenuifolia and development of resistance against grass carp reovirus (GCRV) and Dactylogyrus intermedius in respective host. Fish Shellfish Immunol 41:541-548

Zhang QY, Ruan HM, Li ZQ, Yuan XP, Gui JF (2003) Infection and propagation of lymphocystis virus isolated from the cultured flounder Paralichthys olivaceus in grass carp cell lines. Dis Aquat Org 57:27-34

Zhao Z, Teng Y, Liu H, Lin X, Wang K, Jiang Y, Chen H (2007) Characterization of a late gene encoding for MCP in soft-shelled turtle iridovirus. Virus Res 129:135-144

Zhou Y, Fan Y, LaPatra SE, Ma J, and others (2015) Protective immunity of a Pichia pastoris expressed recombinant iridovirus major capsid protein in the Chinese giant salamander, Andrias davidianus. Vaccine 33:5662-5669

> Zhu B, Liu G, Ling F, Wang G (2015) Carbon nanotubebased nanocarrier loaded with ribavirin against grass carp reovirus. Antiviral Res 118:29-38

Submitted: March 11, 2016; Accepted: August 11, 2016 Proofs received from author(s): October 20, 2016 